\title{
Kokborok: A Major Tribal Language of Tripura
}

\author{
Faijul Hoque
}

\begin{abstract}
The Borok is a major and aboriginal tribe of Tripura. They are with an approximate population of 15 lakh. They have been living in the state since thousand years. The language they speak is called Kokborok. It belongs to Bodo-Garo group of Tibeto-Burman branch of Sino-Tibetan family. The current paper discusses and analyses some important phonological and grammatical feature of Kokborok. At the same time it throws light on a few aspect of ethno-cultural life of Boroks.

Language is human system of communication that uses arbitrary signals such as voice sound, gesture, or written symbols. It is one of the most wonderful creations of man. It may be considered as a tool, instrument or machine of social control. It is a storehouse of knowledge and it transfer knowledge from one person to another and from one generation to another.
\end{abstract}

Broadly speaking, language is asocial event, it can be fully understood and explained only if we know about the people who are involved in it, their personalities, their belief and their attitude, knowledge of words, their relationship to each other and their social status. In a state like Tripura where an aboriginal tribe called BOROK has been living since thousand years. This Borok comprises of 8(eight) major tribal communities having similar culture and life style. They are also recognized as the Borok Race. These tribal communities are Tripuri, Reang, Jamatia, Noatia, Murasing, Koloi, Rupini and Uchoi. Ethnically they are mainly Mongoloids. All these tribal communities have a common language called KOKOBOROK. Kokborok belongs to Bodo-Garo group of Tibeto- Burman branch of Sino-Tibetan family. The term Kokborok is in fact a compound of two main words viz 'Kok' (language) and 'Borok' (human). So the combination of these words means 'language of human being'. However, the second word is used to denote the Borok people. The Boroks are with an approximate population of 15 lakh settled mainly in Tripura and in the Chittagong Hill Tracts of Bangladesh. They are also found in some of the North-Eastern state of India, Myanmar and Nepal.

Kokborok has 8(eight) major dialects and each of these dialects has been named on the basis of a particular tribe. These dialects are: 1. Debbarma (Puran Tripuri), 2. Reang (Bru), 3.Jamatia, 4. Noatia (New Tripuri), 5. Murasing, 6. Uchoi, 7. Koloi and 8. Rupini. There are different opinions regarding the number of subdialect of the above-mentioned 8 (eight) dialect of Kokborok. The sub-dialect may be more familiar as clan and number of clan of each dialect have a distinct identity. Some are based on the name of a famous person and some are on skillfulness of the particular group of people like the handicraft, waving, sweet tune, and good speakers etc. The number of sub-dialect (Binary Debbarma, 2009) of Kokborok is as follows:

1. Debbarma - 11 sub-dialects

2. $\quad$ Reang -17 sub-dialects

3. Jamatia -03 sub-dialects

4. Noatia -21 sub-dialects

5. Murasing - 09 sub-dialects

6. Uchoi - 06 sub-dialects

7. Koloi -08 sub-dialects and

8. Rupini -11 sub-dialects

A close study of Kokborok reveals that there are 8 (eight) vowel sounds in the language and these are: $\mathbf{i}, \mathbf{e}, \mathbf{a}, \boldsymbol{\jmath}, \mathbf{u}, \mathbf{\jmath}, \mathbf{o}, \mathbf{u}$. The high front unrounded vowel ' $\mathbf{i}$ ' and the mid front unrounded vowel ' $\mathbf{e}$ ' are sometimes used interchangeably as disi and desi which means 'a wick'. The typical vowel 'u' of Kokborok is always occurs in the medial position of word, e.g. tury (water), baguy (for), kwčuy (bright). Phonetically speaking, the pronunciation of the vowel ' $\mathbf{u}$ ' of Kokborok may be heard like high back rounded vowel ' $\mathbf{u}$ ' by unaccustomed ear. But during the articulation of this vowel the lips would not be rounded and forward flanged. In other words lips should remain spread as they do in the case of high front unrounded vowel 'i'. Vowel glides or diphthongs such as ai, au, oi, uai are also used mostly in all word position in the language. More over the length of vowels does not affect meaning in this language.

On the other hand Kokborok has 21 consonant sounds and these are: $\mathbf{p}, \mathbf{p h}, \mathbf{b}, \mathbf{t}, \mathbf{t h}, \mathbf{d}, \check{\mathbf{c}}, \breve{\mathbf{c h}}, \mathbf{\mathbf { j }}, \mathbf{k}, \mathbf{k h}, \mathbf{g}, \mathbf{m}, \mathbf{n}, \mathbf{n g}$ (y), r, s, h, l, w, y. An important feature of this language is the use of conjoint letters, e.g.

ph- phai (to come)

th- thailak (Banaba) 


$$
\begin{aligned}
& \text { čh- čhalok (to drive) } \\
& \text { kh- khal (to restrict) } \\
& \text { ng(y)- langta (naked) }
\end{aligned}
$$

The voiceless stop consonant such as $\mathbf{p}, \mathbf{t}, \check{\mathbf{c}}, \mathbf{k}$ and voiced stop consonant such as $\mathbf{b}, \mathbf{d}, \breve{\mathbf{j}}, \mathbf{g}$ are used interchangeably in the language such as

$$
\begin{aligned}
& \text { dapa and daba (smoking pipe) } \\
& \text { sitol and sidol (wet in vapour) } \\
& \text { čwla and ǰwla (males) } \\
& \text { čwk and ǰwk (females) } \\
& \text { doka and doga(door) }
\end{aligned}
$$

The voiceless stop consonants /p, t, $\mathbf{k}$ / and the only voiced stop consonant /g/ occur in all word position but the only voiceless consonant $/ \check{\mathbf{c}} /$ and voiced stop consonants $/ \mathbf{b}, \mathbf{d}, \breve{\mathbf{j}} /$ occur in word initial and medial position but not in final position.

The conjunct consonant is used in the language. Some time they appear to behave as single sound as in br, gn, etc, the two articulation being simultaneous, as

$$
\begin{aligned}
& \text { br- brwi (four) } \\
& \text { gn- gn'ai (drama) } \\
& \text { kr- kra (father in law) } \\
& \text { sa- snai (beyond / over) } \\
& \text { sr- srap (to contact) }
\end{aligned}
$$

Kokborok is a tonal language. The tones are phonemic. There are two different tones in this language: level (normal) and high. Level (normal) tone is as usual, but for high tone glottal sound $/ \mathrm{h} / \mathrm{is}$ used to the particular syllable. For example:

Level (normal) tone
/cha/ 'right'
/lai/ 'easy'
/phai/ 'to come'
/bor/ 'senseless'
/hor/'night'
/tan/'dry land'

\begin{tabular}{|c|c|c|}
\hline & Singular & Plural \\
\hline Finger - & yasi & yasirok \\
\hline Hand- & yak & yakrok \\
\hline Eye - & mokol & mokolrok \\
\hline For human: & Singular & Plural \\
\hline Partner- & $\log i$ & logisong \\
\hline Sister- & bibi & bibisong \\
\hline Brother- & bwta & bwtasong \\
\hline
\end{tabular}

High tone
/chah/'to eat'
/laih/ 'crossed'
/phaih/'to break'
/bohr/'to plant'
/hohr/'to send'
/than/'to cut'

Like other Tibeto-Burman languages Kokborok also has three different tenses viz present, past and future. Kokborok uses suffixes o/di for present action, kha for past action and nai for future action.

$\begin{array}{clll}\text { Root verb } & \text { Present } & \text { Past } & \text { Future } \\ \text { Phai (to come) } & \text { phaio/phaidi } & \text { phaikhai } \\ \text { Example: } & \text { Bo phaio / phaidi (he comes) } & \\ & \text { Bo phaikha (he came) } & \\ & \text { Bo phainai (he will come) }\end{array}$

Every Kokborok tenses have two aspects. 1. Indefinite and 2. Continuous. For indefinite aspect o/di, kha, nai is used at end of the verb as tense marker. On the other hand oi tong /oi toy / is used between the verb and the tense marker, e.g.

\section{Indefinite: $\quad$ Ang chao/chadi (I eat) \\ Continuous: Ang chaoitongo (I am eating)}

In Kokborok we find two numbers: singular and plural. The plural marker is used at the end of the noun/pronoun. There are two plural markers 'rok' and 'song'. The former is used universally and the later is used with human nouns only, e.g.

For specific quantification the specific number is used and no plural suffixes are added, e.g.

$$
\begin{array}{ll}
\begin{array}{l}
\text { Kolom } \\
\text { (pen) }
\end{array} & \begin{array}{l}
\text { kongso= a pen } \\
\text { (one) }
\end{array} \\
\text { Gari } & \begin{array}{l}
\text { khungsa = a car } \\
\text { (car) }
\end{array} \\
\text { (one) }
\end{array}
$$




\section{Rang khokchai $=$ ten rupees \\ (rupees) (ten)}

Gender is denoted by different words in case of human being, e.g.

Pha- father

$\mathrm{Ma}$ - mather

Hik- wife

Sai- husband

Cherai- boy

Kirijaknai- girl

Sajla- son

Sajwak- daughter

\section{Masculine}

Pun (goat)- $\quad$ punjua (he goat)

Tok (fowl)- tokchwla (cock)

Takhum (swan)- takhumchwla (darke)

\section{Feminine}

punjuk (she goat)

tokma (hen)

takhumbwrwi(duck)

Another noteworthy feature of the language is that adjectives are placed after the noun they qualify, as

Cherai kham $=$ good boy

(boy) (good)

Bufang kotor= big tree

(tree) (big)

Kokborok uses postposition. When the postposition 'o' is added with any noun and the final sound of that noun is either voiceless stop ' $\mathbf{p}$ ' or ' $\mathbf{k}$ ' then these final voiceless stop sounds change into voiced stop ' $\mathbf{b}$ ' or ' $\mathbf{g}$ ' respectively, e.g.
Koklop(poem),
koklop $+\mathrm{o}=$ koklobo
(in poem)
Paithak(last),
paithak $+\mathrm{o}=$ paithago
(in last)

The personal pronoun has three persons but no gender in Kokborok, as
Ang (I)
Chwng (we)
Nwng (you)
Nohrok (you all)
Bo (he/she)
Bohrok (they)

The word order in sentence of Kokborok is SOV i.e subject, object and verb, e.g.

$\begin{array}{lll}\mathrm{Ram} & \text { mai chao } \\ \mathrm{Ram} & \text { rice } & \text { eat-pesent }\end{array}$

(S) (O) (V)

Ram eats rice.

The word order of the interrogative sentence is genitive/possessive+subject+question, e.g
Nini mung tamo?
Your name what
What is your name?

The word order of the imperative sentence is $\mathbf{S}+\mathbf{V}+\mathbf{C o m m a n d}$, e.g

Nwng thangdi
You go-command

You go.

Kokborok generally uses ' $y a$ ' as negation in the end to form a negative sentence. The principle structure of negative sentence is $\mathbf{S}+\mathbf{O}+\mathbf{V}+\mathbf{N e g}$, e.g

$$
\begin{aligned}
& \text { Ram mai cha ya } \\
& \text { Ram rice eat not }
\end{aligned}
$$

Ram does not eat rice.

' $\boldsymbol{J a}$ ' and 'Nohrok' the two honorific terms are used in Kokborok for request and expressing courtesy. ' $\boldsymbol{J a}$ ' is used between the verb and the tense marker and 'Nohrok' is used in the beginning always, e.g.

Ja- phaijadi (please come)

Nohrok- Nohrok achukjadi (please take seat)

The suffixes 'mung', 'thai' and 'nai' are used with root verb to form a noun, e.g.

Chah (to eat) - Chah+mung = Chahmung (food)

-Chah+thai= Chahthai (food)

-Chah+nai= Chahnai (eater)

Kokborok numerals are both decimal and bi-decimal. The decimal numerals are:

$\mathrm{Sa}-$ one

Nwi- two 


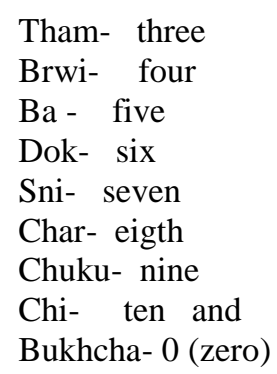

The bidecimal numerals are organized in the following way:

Chisa $=$ chi+sa $($ ten + one $)=$ eleven $=11$

Nwichisa $=$ nwi+chisa $($ twenty+one $)=$ twentyone $=21$

Thamchidok $=$ tham + chi + dok $($ three+ten + six $)=$ thirtysix $=36$

Charchitham $=$ char + chi + tham $($ eight + ten + three $)=$ eightythree $=83$

Chukuchisni $=$ chuku+chi+sni $($ nine+ten + seven $)=$ ninetyseven $=97$

Several types of Deixis for instance person deixis, place deixis and time deixis are also used in Kokborok. For different deixis different words are used, as

$\begin{array}{lll}\text { Person deixis: } & \text { Bo (he/she) }- & \text { Bohrok (they) } \\ \text { Place deixis: } & \text { Oro (here) }- & \text { Uro (there) } \\ & \text { Obo/mo (this) }- & \text { Abo (that) } \\ \text { Time deixis: } & \text { Tini (to day) - } & \text { Khwna (tomorrow) }\end{array}$

The culture of the Borok, which is obviously different from others in many respects, is reflected by their use of special words for different kinds of action and object. Thus for instance, they make use of several words for different types of baskets, ornaments, dresses etc. All these objects of different sizes and shapes are indispensable for their daily life and they have many names for which we may have only one general term, e.g.

Baskets:

Langa/Nokhai $=$ basket for carrying paddy, grains, pulses etc.

Teseng/Dingra $=$ basket for carrying fire wood, vegetable, utensils etc.

Takhuk = basket for carrying cock, hen etc.

Ornaments:

Japa/Sauma = basket for carrying cosmetic item such as face powder, kajal, cream etc.

$$
\begin{aligned}
& \text { Chadrahar = necklace } \\
& \text { Rangtamag = necklace made of coins } \\
& \text { Sangi = a needle used to tight a bun } \\
& \text { Surma = one type of chain used in hair } \\
& \text { Bala-kharu = one kind ornament used in hand } \\
& \text { Anchili = one kind ornament used in legs }
\end{aligned}
$$

Dresses:

Risa = upper part of garment of the Borok women

Rignai = lower part of garment of the Borok women

Similarly, the socio-cultural and socio-religious life style of the Borok contributes much in forming the speech forms. They make use of different words for the village chief and religious head, e.g.

$$
\begin{aligned}
& \text { Naran }=\text { head of the society } \\
& \text { Roaza }=\text { head of the village } \\
& \text { Pomang }=\text { head of the council } \\
& \text { Taimang = assistant of Pomang } \\
& \text { Ochai = head priest } \\
& \text { Baroa = assistant of Ochai }
\end{aligned}
$$

Kokborok is famous for wits and the language contains many witty expression and proverbs which is called kok-hajakma. Some proverbs produce a clever type of humour and full of wisdom. For illustration a few proverbs or saying are given here:

1. Dangai pho bokha bising kabo

(Sufferers can realize the sorrows of others)

2. Beng-nog beng nango

(One who digs a well for others, he himself falls in)

3. Siyari bai twima ongia

(Fog cannot create a river)

4. Sa haya hai bithi rukh

(Right medicine is being served for a right desease) 


\section{Borok ahai sao}

(Speech is the man's identity)

The vocabulary of Kokborok is also based on the Borok's settlement pattern, family structure, occupation, marriage, religion etc. Generally, Boroks live in a 'Nok-Chuk' (tong) or pile house on hill tops and slopes in a group. They construct their houses five to six feet high from the ground in order to escape from the attack of wild animals. Those who lives in the plains and foot hills, they make their houses similar to that of Bagalees. They live in a small group of 5 to 30 families in their selected place known as 'kami'or 'parah' which usually bear the name of their sardar or Head man.The ground, just below the hut ,is fenced off and used to keep domestic animals like hens, cattle, pigs etc. The hut of the Head man or sardar of the parah is situated among them in the middle part. Each family which is known as khana lives in a separate hut. They have both nuclear and extended families but the number of nuclear ones is increasing. Their families are male dominated and in the absence of father, the eldest son succeeds to his father's authority. The Borok women collect fuel, fodder and drinking water for their families. Thy also take part in economic, social, ritual, religious and political activities, and contribute to their family income.

Shifting cultivation called Jhum/Hook is the primary occupation of the Borok. Gharchukti (house tax) is levied to the Hook-Chanai (shifting cultivators). Previously their Roaza (Head man) was to allot the Hook-Lambi (Jhum area) for each house owner. They are now mostly engaged in settled cultivation, with the continuation of the old practice. Their main crops are: paddy, maize, cotton, cucumber, pumpkin, gourd, jungle potato etc. Agriculture is their main source of livelihood. The crops are cultivated in three types of land viz upland, intermediate land and low land.

The Borok practices adult marriage and are monogamous. Among them three types of marriage are there: (a) Khogwi kaijakmani (b) Kokswngwi kailaimani and (c) Chamrwi kamani/ Chamrwi Omor. In all these three types of marriages the Ochai (priest) performs all the rituals and finally tie the knot as husband and wife. Besides this the Ochai also performs all sorts of rituals and ceremonies in Borok community. The first type of marriage is by mutual consent between the boy and the girl. For this, there is no elaborate ritual for their marriage. A feast is given to the friends and relatives. The second type of marriage is performed through negotiation between the parents of the boy and the girl. In third type of marriage the groom stays in in-laws house for a certain period of time which may sometime for whole life after marriage. There is another type of marriage called Kharlaioi kaijakmani (marriage by elopement). A boy and a girl run away and get married without the approval of their respective parents or guardians. This type of marriage is now a days very common. But once it was restricted by their social council. This practice is taken up now to avoid paying dowry or bride price. Another type of marriage is called Chamari amar (marriage by service). In earlier days the prospective bridegroom had to stay for one year in the house of the bride before his marriage and to extent his assistance in agricultural activities of the bride's house. Now it is simplified by paying bride-price in cash. Widow remarriage and divorce are allowed. Generally, the Boroks practice monogamy but richer among them occasionally practice polygamy. Either the husband or the wife can seek divorce on the ground of adultery, maladjustment, impotency and some other reasons. Children can stay with either the mother or the father after the divorce. A widow can marry his deceased wife's younger sister.

By religion Boroks are now under Hindu inspiration. But they were previously animist. They had their tribal religion modified by Hinduism. The Chantai (the Borok high priests) and the Deodias (the assistant priests) are regarded as the custodians of their religion and occupy as exalted a position in society as the Brahmin in Hindu society. There are many gods worshipped by the Boroks have different names in their language, such as:

Tuima (water goddess / Ganga)

Khuluma (goddess of cotton plant)

Mailu-ma (Lakshmi)

Matai-garja (Shiv Mahadev)

San-Grama (goddess of sky, sea and mountain)

The Boroks has been a long association with the Bengalees. As a result Kokborok has borrowed many words form Bangla with a minor modification and enlisted in Kokborok vocabulary. These borrowed words bear much resemblance with Bangla. Some of these borrowed words are given below which are differing with Kokborok only in retroflex sounds because Bangla uses retroflex but Kokborok does not, e.g.

Kokborok

berai

bora

pori

dila

\section{Bangla}

berai (to move)

borra (bread)

pori (to read)

dila (slow)

The modern Boroks are multilingual. Apart from Kokborok they also can speak Bengali, Hindi and English fluently. Always they prefer English as a medium of communication. 
Kokborok had a script called Koloma. As the days passed it lost its own script. Later on the Borok started writing their language using Bangla script. But again, to them Bangla script was not suitable for their language. The educated Borok started searching for a suitable script with scientific basis to write their language. They found Roman is the most scientific script for their mother tongue. Therefore $90 \%$ of the Borok people now have started writing Kokborok in Roman script. However, a very negligible percentage of people are using Bengali script for Kokborok.

Kokborok now is a distinct language and is recognized by the Tripura government as a state language as well as official language along with Bangla. Now a days, Kokborok is taught in schools, college and University level as well. The language is also widely used in both print media and mass media. It can be said that efforts for all round development of the language are going on. These will definitely bear fruits in the days to come.

\section{References:}

[1]. Acharyya, R.K. 2007 (ed) Development of Tribal Languages. Agartala; Tribal Research Institute, Govt. of Tripura.

[2]. Boro, M.R. 1990. The Historical Development of Boro Language. Hajo, Priyadini Brahma.

[3]. Chatterjee, Suhas 1972. Tripurar Kagbarak Bhashar Likhita Rupe Uttaron. Kolkatta

[4]. Chakarborty, S.K. 1981, A Study of Tipura language .Agartala: Parul Prakashan.

[5]. Choudhury, K.K. 2007 Kokborok A promising Tribal language of North East India. Agartala: Akshar publication.

[6]. Debbarma, Radha Mohan, 1900. Kokborokma: A grammar of Tripura language. Comilla, Afazuddin Ahmmad.

[7]. Grierson, G.A. 1903/reprint 1967. Linguistic Survey of India 3:2. Delhi. Motilal Banarasidass.

[8]. Karapurkar, Pushpa, 1976. Kokborok Grammar. Mysore. Central Institute of Indian Languages.

[9]. Saha,S.B. 1988 Origin and Structure of Kakbarak: A tribal language. Agartala. Rupali Publishing.

[10]. Sandys, E.F, et al. 1915 (ed). History of Tripura. Agartala. Tripura State Tribal Research Institute and Museum, Govt. of Tripura. 